\title{
Hubungan Kompensasi Finansial dengan Kinerja Karyawan Kontrak PT Unilever Body Care Indonesia Tbk
}

\author{
Tiara Suciaty \\ Departemen Manajemen, Fakultas Ekonomi dan Manajemen \\ Institut Pertanian Bogor \\ Kampus Darmaga Bogor 16680 \\ Siti Rahmawati \\ Departemen Manajemen, Fakultas Ekonomi dan Manajemen \\ Institut Pertanian Bogor \\ Kampus Darmaga Bogor 16680 \\ e-mail: sitirahmawatiipb@gmail.com
}

\begin{abstract}
Companies needs to create strategies to satisfy their employeeswhich finally result in positive impacts for the companies. One of those strategies to provide appropriate compensation. The aims of this research are 1) to discover the implementation of financial compensation according to the contract employees of PT Unilever Body Care Indonesia Tbk (ULBC); 2) to reveal the performance of PT ULBC contract employees; and 3) to identify the relation between financial compensation and the performance of PT ULBC contract employees. Data taken were both primary and secondary data. This research also uses Pearson Product Moment correlation analysis. Based on the perception of employees about financial compensation and contract employee performance, it was found that both of them are suitable with their hopes. The results of correlation between financial compensation and employees' contract performance is 0.813 , showing a positive and strong relation. This means that, financial compensation can increase the performance of PT ULBC's contract employee.

Keywords: financial compensation, employee performance, PT Unilever Body Care Indonesia Tbk
\end{abstract}

\begin{abstract}
ABSTRAK
Perusahaan perlu membuat strategi untuk menciptakan kepuasan bagi karyawan, sehingga berdampak positif untuk perusahaan. Salah satunya adalah memberikan kompensasi yang tepat. Tujuan penelitian ini adalah : 1) Mengetahui pelaksanaan kompensasi finansial menurut karyawan kontrak PT Unilever Body Care Indonesia Tbk (ULBC); 2) Mengetahui kinerja karyawan kontrak PT ULBC; dan (3) Mengidentifikasi hubungan kompensasi finansial dengan kinerja karyawan kontrak PT ULBC. Data bersumber dari data primer dan sekunder. Penelitian menggunakan analisis korelasi Pearson Product Moment. Berdasarkan persepsi karyawan kontrak mengenai kompensasi finansial dan kinerja karyawan kontrak menunjukkan bahwa, kompensasi finansial dan kinerja karyawan kontrak telah sesuai dengan harapan karyawan. Hasil uji korelasi antara kompensasi finansial dengan kinerja karyawan kontrak sebesar 0.813 menunjukkan hubungan positif dan kuat. Hal ini mengindikasikan bahwa, kompensasi finansial dapat meningkatkan kinerja karyawan kontrak PT ULBC.

Kata Kunci: kompensas finansial, kinerja karyawan, PT Unilever Body Care Indonesia Tbk
\end{abstract}

\section{Pendahuluan}

Sumberdaya manusia merupakan aset penting bagi perusahaan. Arep dan Tanjung (2003) menjelaskan bahwa manajemen sumberdaya manusia adalah ilmu dan 
seni yang mengatur unsur manusia (cipta, rasa, dan karsa) sebagai aset suatu organisasi demi terwujudnya tujuan organisasi dengan cara memperoleh, mengembangkan, dan memelihara tenaga kerja secara efektif dan efisien, sehingga perusahaan dapat berkembang dengan baik. Supplytenaga kerja yang cenderung lebih tinggi dari demand membuat perusahaan memiliki keleluasaan untuk memberikan gaji yang relatif rendah kepada karyawan. Namun, perusahaan tetap perlu menyusun strategi yang tepat sehingga dapat menciptakan kepuasan bagi karyawan dan memberi dampak positif untuk perusahaan. PT Sara Lee Body Care Indonesia Tbk (PT Sara Lee) diakuisisi oleh Unilever Indonesia Holding BV pada Desember 2010 dan berubah nama menjadi PT Unilever Body Care Indonesia Tbk (PT ULBC) pada tanggal 25 Januari 2011. Pada masa transisi atau peralihan operasi perusahaan dari PT Sara Lee kepada PT ULBC pada tahun 2010-2011 terjadi penurunan kinerja perusahaan yang menyebabkan penurunan penjualan sebesar 9\% (PT ULBC 2012). Hal ini disebabkan adanya aksi mogok kerja yang dilakukan oleh karyawan PT Sara Lee beberapa minggu sebelum akuisisi dilakukan. Aksi tersebut dipicu oleh adanya tuntutan mengenai perbaikan upah, perbaikan sistem jaminan sosial, perbaikan sistem manajemen perusahaan, dan sejumlah tuntutan lainnya. Hal ini membuat aktivitas kantor dan pabrik mengalami masalah yang mengganggu pengiriman barang dan mempengaruhi penjualan dalam dan luar negeri.

Sejak saat itu, perusahaan mulai menggunakan tenaga kerja kontrak dalam menjalankan kegiatan operasionalnya. Salah satu alasan perusahaan mempekerjakan karyawan secara kontrak karena perusahaan membutuhkan tenaga ahli yang tidak dimiliki perusahaan untuk menangani suatu pekerjaan khusus dalam jangka waktu tertentu. Biaya yang dikeluarkan oleh perusahaan relatif lebih efisien dengan menggunakan karyawan kontrak karena perusahaan tidak perlu mengeluarkan biaya tambahan untuk pelatihan dan pengembangan karyawan. Data jumlah karyawan PT ULBC tersebut dapat dilihat pada Tabel 1.

Tabel 1. Jumlah karyawan PT ULBC

\begin{tabular}{|c|c|c|}
\hline No. & Periode & Jumlah Karyawan \\
\hline 1. & 30 Juni 2010 & $\begin{array}{l}399 \text { karyawan } \\
\text { (162 karyawan tetap dan } 237 \text { karyawan yang bersumber dari pihak ketiga) }\end{array}$ \\
\hline 2. & 30 Juni 2011 & $\begin{array}{l}357 \text { karyawan } \\
\text { (13 karyawan tetap, } 107 \text { karyawan kontrak, dan } 237 \text { karyawan yang } \\
\text { bersumber dari pihak ketiga) }\end{array}$ \\
\hline 3. & 30 Juni 2012 & $\begin{array}{l}335 \text { karyawan } \\
\text { ( } 7 \text { karyawan tetap, } 91 \text { karyawan kontrak, dan } 237 \text { karyawan yang } \\
\text { bersumber dari pihak ketiga) }\end{array}$ \\
\hline
\end{tabular}

Sumber: PT ULBC (2012)

Permasalahan yang ada pada PT ULBC adalah kinerja karyawan kontrak yang masih kurang baik. Hal ini dilihat dari tingkat kehadiran karyawan masih belum memuaskan. Karyawan kontrak masih banyak yang datang terlambat, istirahat sebelum waktunya, pulang lebih awal dan alasan lainnya, seperti ada urusan keluarga, sakit, maupun pergi keluar kantor. Permasalahan pada PT ULBC ini sejalan dengan permasalahan yang dikemukan oleh Nasution (2013) pada penelitiannya yang menyebutkan bahwa kompensasi yang diberikan belum memenuhi harapan karyawan, 
misalnya gaji karyawan belum cukup memenuhi kebutuhannya dan lain sebaginya, sehingga perusahaan jarang menyebabkan tingkat kepuasan kerja karyawan menurun. Hal ini dapat dilihat dari adanya beberapa karyawan yang sering terlambat masuk kerja, tidak mencapai target kerja yang ditetapkan, pekerjaan yang dilaksanakan kurang akurat dan lain sebagainya. Data tingkat kehadiran karyawan kontrak PT ULBC periode Juli 2012-Juni 2013 dapat dilihat pada Gambar 1.

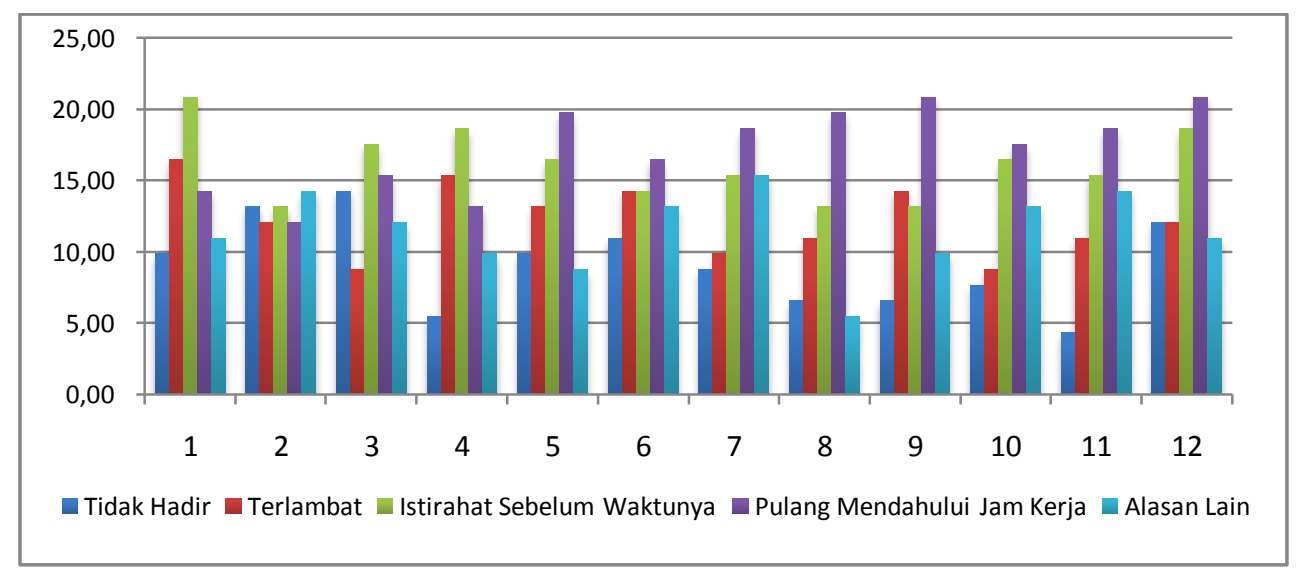

Gambar 1. Tingkat kehadiran karyawan kontrak PT ULBC periode Juli 2012-Juni 2013

Tingkat kehadiran karyawan kontrak PT ULBC periode Juli 2012-Juni 2013 cenderung berfluktuatif. Karyawan kontrak PT ULBC yang pulang mendahului jam kerja memiliki persentase paling tinggi dengan rata-rata $17.31 \%$. Dalam hal ini manajemen perusahaan perlu mengelola sumber daya manusia yang dimiliki agar dapat menghasilkan kepuasan kerja karyawan dan mengoptimalkan kinerja karyawan. Terkait manajemen sumber daya manusia (SDM) menurut Marwansyah (2010) terdapat sejumlah fungsi operasional, yakni: perencanaan SDM, rekrutmen dan seleksi, pengembangan SDM, kompensasi, keselamatan dan kesehatan kerja, hubungan industrial, dan penelitian SDM. Beberapa cara yang dapat diupayakan oleh perusahaan untuk mengoptimalkan kinerja karyawan, termasuk karyawan kontrak, diantaranya melalui pendidikan, pelatihan, pemberian kompensasi yang layak, menciptakan lingkungan kerja yang kondusif dan pemberian motivasi (Lizar dan Sudiro 2013).

Saat ini kompensasi tidak hanya memiliki beberapa fungsi yang sederhana dan tradisional, tetapi juga telah dipercayakan dengan banyak konotasi baru. Manajemen kompensasi sudah erat kaitannya dengan strategi pengembangan usaha dan pengembangan sumber daya manusia (Fu 2012). Menurut Rivai (2006) pada dasarnya kompensasi dibedakan menjadi dua kelompok, yaitu kompensasi finansial dan kompensasi non finansial. Kompensasi finansial terdiri dari dua macam, yaitu kompensasi finansial langsung dan kompensasi finansial tidak langsung. Perusahaan dapat memberikan kompensasi berupa kompensasi finansial langsung dan kompensasi finansial tidak langsung secara adil dan layak bagi karyawan untuk meningkatkan kinerja karyawan pada perusahaan tersebut..Kompensasi yang dikelola dengan baik dapat membantu perusahaan dalam memperoleh, memelihara, serta menjaga karyawannya. Masalah kompensasi tidak hanya penting karena menjadi dorongan 
utama seseorang menjadi karyawan, tetapi juga besarnya pengaruh kompensasi terhadap semangat dan kegairahan kerja para karyawannya (Rivai 2006) dapat menciptakan suasana kerja yang menyenangkan dan menciptakan kepuasan bagi karyawan, sehingga dapat meningkatkan kinerja karyawan.

Perusahaan dapat berkembang jika dikelola dengan baik, dan peran sumber daya manusia menjadi hal penting di dalamnya. Perusahaan dalam menggunakan tenaga kerja secara kontrak perlu mempertimbangkan kompensasi finansial untuk karyawannya, sehingga menciptakan kepuasan bagi karyawan dan berdampak positif untuk perusahaan.

Tujuan dari penelitian ini adalah : 1) Mengetahui pelaksanaan kompensasi finansial menurut karyawan kontrak PT ULBC;2) Mengetahui kinerja karyawan kontrak PT ULBC; dan 3) Mengidentifikasi hubungan kompensasi finansial dengan kinerja karyawan karyawan kontrak PT ULBC.

\section{Metode Penelitian}

Sumberdaya manusia dalam suatu perusahaan berperan penting dalam menjalankan aktivitas perusahaan. Karyawan pada PT ULBC terbagi menjadi 3, yaitu karyawan tetap, karyawan kontrak, dan karyawan yang bersumber dari pihak ketiga. Perusahaan perlu membuat kebijakan untuk menciptakan kepuasan kerja bagi karyawannya, salah satunya terkait dengan pemberian kompensasi finansial. Kompensasi finansial yang dimaksud meliputi, kompensasi finansial langsung berupa pembayaran pokok, pembayaran prestasi, pembayaran insentif, dan pembayaran tertangguh, dan kompensasi finansial tidak langsung berupa proteksi, komisi luar jam kerja, dan fasilitas.

Saat ini, PT ULBC banyak melibatkan karyawan kontrak dalam menjalankan kegiatan operasionalnya. Kompensasi finansial tersebut akan diidentifikasi hubungannya dengan kinerja karyawan yang terdiri dari tiga aspek yaitu, kemampuan teknis, kemampuan konseptual, dan kemampuan hubungan interpersonal. Kerangka berpikir dalam penelitian ini dapat dilihat pada Gambar 2.

Penelitian dilakukan di PT ULBC yang terletak di Jalan Raya Bogor Km. 27 Ciracas Jakarta Timur 13740. Waktu pelaksanaan penelitian dimulai dari bulan Maret 2013 hingga Juni 2013. Pemilihan lokasi penelitian dilakukan secara sengaja dan atas kesediaan PT ULBC dan kemudian menemukan permasalahan untuk diteliti, yaitu mengenai kompensasi finansial dan kinerja karyawan kontrak pada PT ULBC.

Penelitian ini menggunakan data primer dan sekunder, dimana data primer diperoleh dari pengamatan langsung di perusahaan, wawancara kepada responden, dokumentasi perusahaan, dan kuesioner. sedangkan data sekunder diperoleh dari buku dan literatur lainnya yang berhubungan dan mendukung penelitian ini. Kuesioner yang digunakan dalam penelitian ini terbagi menjadi tiga bagian. Bagian pertama berkaitan dengan identitas responden, bagian kedua memuat pernyataaan tertutup mewakili variabel yang berkaitan dengan kompensasi finansial, dan bagian ketiga berisi variabel yang berkaitan dengan kinerja karyawan. 


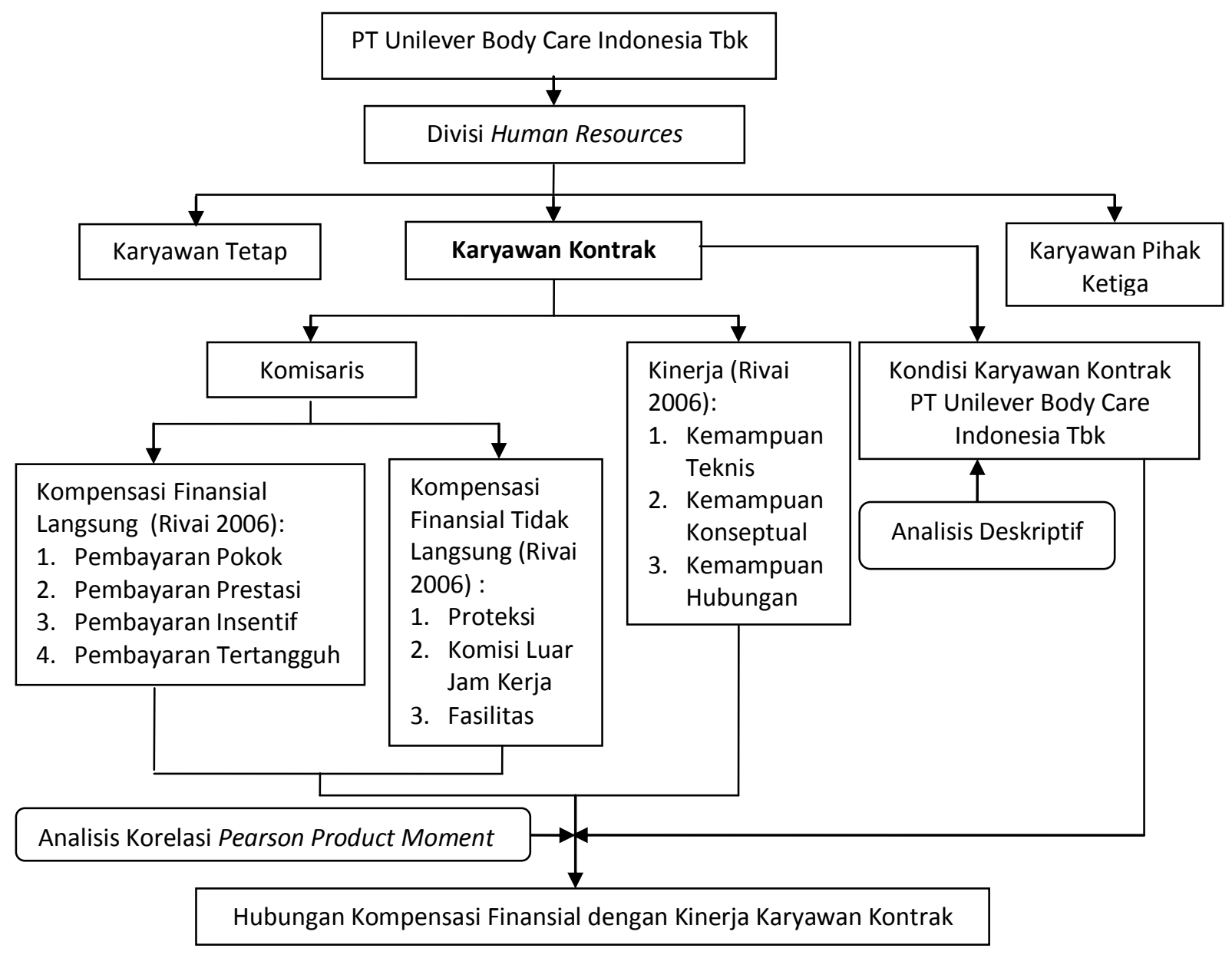

Gambar 2. Kerangka pemikiran penelitian

Pengolahan data dilakukan menggunakan Microsoft Office Excel 2007 dan software Statistical Package for Social Science (SPSS) 17 terhadap 91 responden. Pengolahan data menggunakan analisis deskriptif dan analisis korelasi Pearson Product Moment. Data hasil pengisian kuesioner dianalisis secara deskriptif dengan menggunakan skala Likert, yaitu: (1) Sangat Tidak Setuju, (2) Tidak Setuju, (3) Cukup Setuju, (4) Setuju, (5) Sangat Setuju. Analisis deskriptif dilakukan menggunakan modus untuk mengetahui skor yang memiliki frekuensi terbanyak dan analisis korelasi Pearson Product Moment digunakan untuk menentukan besaran yang menyatakan hubungan antar variabel.

Hipotesis digunakan untuk mengetahui signifikansi angka korelasi pada penelitian ini, yaitu:

$\mathrm{HO}$ : tidak terdapat hubungan antara kompensasi dengan kinerja karyawan

$\mathrm{H} 1$ : terdapat hubungan antara kompensasi dengan kinerja karyawan.

\section{Hasil dan Pembahasan}

III.1. Gambaran Umum Perusahaan

PT ULBC merupakan perusahaan Fast Moving Consumer Goods (FMCG) yang bergerak di bidang pembuatan produk perawatan kulit dan tubuh untuk dewasa, anak- 
anak, dan bayi. Produk personal care perseroan terdiri dari merek Zwitsal, She, Brylcreem, dan Purol. Perusahaan berlokasi di Jl. Raya Bogor Km. 27 Ciracas Jakarta Timur 13740, sedangkan kantor pusat berlokasi di Gedung Graha Unilever Lantai 8 Jl. Gatot Subroto Kav. 15 Jakarta Selatan 12930. PT ULBC mempunyai visi menjadi pilihan pertama konsumen, pelanggan, dan komunitas. Misi dari PT ULBC adalah memberi kepuasan tertinggi kepada konsumen dan pelanggan setiap berinteraksi dengan produk PT ULBC. Tujuan umum PT ULBC adalah menyediakan produk yang aman dari segi rancangan maupun penggunaan, agar secara konsisten dapat memenuhi kebutuhan konsumen dan pelanggan, serta harapan mereka terhadap kualitas yang baik. Perusahaan memiliki komitmen tinggi dalam menjalin hubungan yang saling bermanfaat dengan para pemasok, pelanggan, dan mitra usaha. Mitra usaha yang berelasi dengan PT ULBC dalam penjualan barang jadi diantaranya yaitu, Unilever Asia Private Limited, Unilever Supply Chain Company, Unilever Hongkong Limited, Unilever Japan Customer, Unilever Philippines, Hindustan Unilever Limited, serta PT Unilever Indonesia (PT ULBC 2012).

PT ULBC dipimpin oleh seorang Presiden Direktur dan didukung oleh 6 divisi yang dipimpin oleh masing-masing direktur, yaitu Divisi Keuangan, Divisi Operasi, Divisi Pemasaran, Divisi Rantai Pasok, Divisi Sumberdaya Manusia, dan Divisi Penjualan. Struktur organisasi PT ULBC secara lengkap dapat dilihat pada Gambar 3.

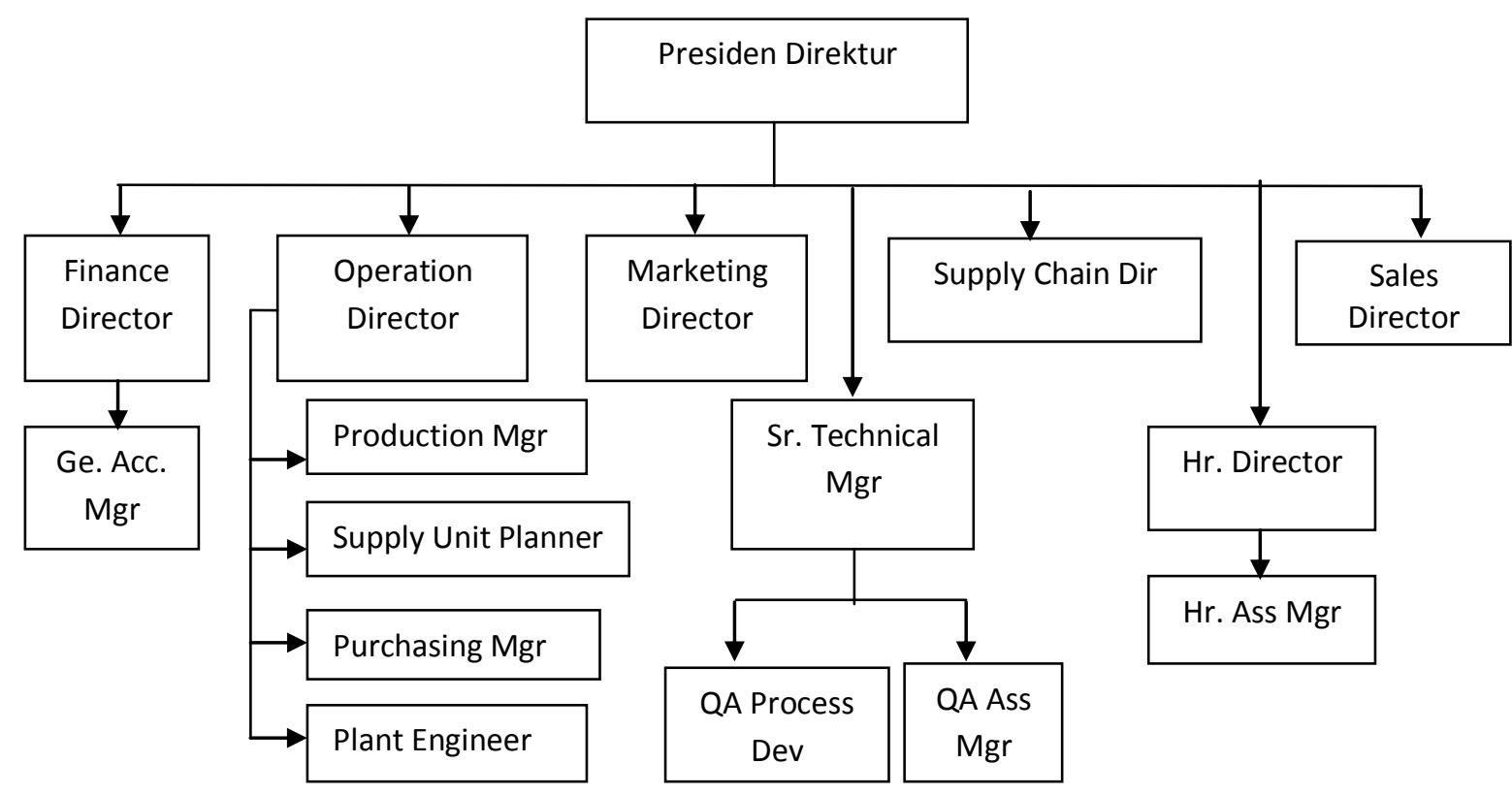

Gambar 3. Struktur organisasi PT ULBC Sumber: PT ULBC (2012)

Jumlah karyawan PT ULBC sebanyak 335 karyawan dengan 7 karyawan tetap, 91 karyawan kontrak, dan 237 karyawan yang bersumber dari pihak ketiga. Fungsi dan jabatan karyawan tetap dan karyawan kontrak dapat dilihat pada Tabel 2 dan 3. 
Tabel 2. Jumlah karyawan tetap pada setiap fungsi dan jabatan

\begin{tabular}{llc}
\hline \multicolumn{2}{c}{ Karyawan Tetap PT ULBC } \\
\hline No. & \multicolumn{1}{c}{ Fungsi dan Jabatan Karyawan } & Jumlah Karyawan \\
\hline 1. & Gen. Accounting Manager & 1 \\
2. & Production Manager & 1 \\
3. & Supply Unit Planner & 1 \\
4. & Purchasing Manager & 1 \\
5. & Plant Engineer & 1 \\
6. & Sr. Technical Manager & 1 \\
7. & QA Asst. Manager & 1 \\
\hline
\end{tabular}

Tabel 3. Jumlah karyawan kontrak pada setiap fungsi dan jabatan

\begin{tabular}{|c|c|c|c|c|c|}
\hline \multicolumn{6}{|c|}{ Karyawan Kontrak PT ULBC } \\
\hline No. & $\begin{array}{c}\text { Fungsi dan Jabatan } \\
\text { Karyawan }\end{array}$ & $\begin{array}{c}\text { Jumlah } \\
\text { Karyawan }\end{array}$ & No. & $\begin{array}{c}\text { Fungsi dan Jabatan } \\
\text { Karyawan }\end{array}$ & $\begin{array}{l}\text { Jumlah } \\
\text { Karyawan }\end{array}$ \\
\hline 1. & Application Support & 1 & 18. & Production Admin & 2 \\
\hline 2. & Chief Manufacturer & 1 & 19. & Purchasing Admin & 1 \\
\hline 3. & Corporate Accounting & 1 & 20. & Production Supervisor & 1 \\
\hline 4. & $\begin{array}{l}\text { Cost Accounting } \\
\text { Asst.Manager }\end{array}$ & 2 & 21. & Production Asst.Supervisor & 2 \\
\hline 5. & Document Data Controller & 1 & 22. & Regulatory Asst.Manager & 1 \\
\hline 6. & Graphic Designer & 1 & 23. & R \& D Chemist & 1 \\
\hline 7. & HR Asst.Manager & 1 & 24. & R \& D Technician & 1 \\
\hline 8. & In Process Control & 1 & 25. & QA Analyst & 5 \\
\hline 9. & IPC Officer & 1 & 26. & Scale Up \& FG Leader & 1 \\
\hline 10. & Legal Asst.Manager & 1 & 27. & Scale Up Supervisor & 1 \\
\hline 11. & Line Leader & 5 & 28. & Secretary Operation & 1 \\
\hline 12. & Logistic Planner & 1 & 29. & Spare Part Controller & 1 \\
\hline 13. & Machine Operator & 25 & 30. & Tax Account Supervisor & 1 \\
\hline 14. & Manufacturer & 13 & 31. & Tax Admin & 1 \\
\hline 15. & Microbiologis & 1 & 32. & Technician & 11 \\
\hline 16. & $\begin{array}{l}\text { Outbound Logistic } \\
\text { Supervisor }\end{array}$ & 1 & 33. & $\begin{array}{l}\text { Treasury \& Payroll } \\
\text { Asst.Manager }\end{array}$ & 1 \\
\hline 17. & Personnel Admin & 1 & 34. & WH Supervisor & 1 \\
\hline
\end{tabular}

Sumber: Data diolah (2013)

III.2. Uji Validitas dan Reliabilitas

Peubah yang digunakan adalah kompensasi finansial (X1) yang terdiri dari pembayaran pokok, pembayaran prestasi, pembayaran insentif, pembayaran tertangguh, proteksi, komisi luar jam kerja, dan fasilitas. Kinerja (X2) terdiri dari kemampuan teknis, kemampuan konseptual, dan kemampuan hubungan interpersonal. Hasil uji validitas digunakan untuk mengetahui nilai korelasi setiap peubah dengan membandingkan skor total item dengan $r$ table. Jumlah data $(n)$ sebanyak 40 mendapatkan hasil $r$ hitung lebih besar dari 0.361 dengan taraf nyata 0.05 , sehingga peubah dinyatakan valid. Hasil uji reliabilitas diketahui nilai reliabilitas (alpha cronbach) tiap peubah lebih besar dar 0.6 yaitu, $\mathrm{X}_{1}=0.730$ dan $\mathrm{X}_{2}=0.703$ yang mengindikasikan bahwa alat ukur tersebut reliabel. 


\section{III.3. Karakteristik Responden}

Responden dalam penelitian ini adalah karyawan kontrak PT ULBC sejumlah 91 orang. Karakteristik responden ditinjau dari segi jenis kelamin, usia, pendidikan, masa kerja, pendapatan karyawan, dan jumlah tanggungan. Data karakteristik responden dapat dilihat pada Tabel 4.

Tabel 4. Karakteristik Responden

\begin{tabular}{cllc}
\hline No & & Karakteristik Responden & Persentase Responden \\
\hline 1. & Jenis Kelamin & Laki-Laki & 80.2 \\
& & Wanita & 19.8 \\
\hline 2. & Usia & $21-30$ tahun & 48.4 \\
& & $31-40$ tahun & 33 \\
& & $41-50$ tahun & 15.4 \\
\hline 3. & Pendidikan & SMA & 58.2 \\
& & STM & 9.9 \\
& & Diploma & 14.3 \\
& & S1 & 15.4 \\
& & S2 & 2.2 \\
\hline 4. & Masa Kerja & 1 tahun & 4.4 \\
& & 2 tahun & 46.4 \\
& & Rp 2 500 000-Rp 3 500 000 & 49.5 \\
\hline 5. & Pendapatan & Rp 3 500 001-Rp 4 500 000 & 66 \\
& & Rp 4 500 001-Rp 5 500 000 & 17 \\
& & $>$ Rp 5 500 000 & 7 \\
& & tidak ada & 10 \\
\hline 6. & Jumlah Tanggungan & 1-2 orang & 22 \\
& & $>2$ orang & 62.6 \\
\hline
\end{tabular}

Mayoritas karyawan kontrak PT ULBC berjenis kelamin laki-laki dengan persentase sebesar $80.2 \%$, dan pada rentang usia 21-30 tahun memiliki persentase tertinggi yaitu sebanyak $48.4 \%$. Karyawan kontrak dengan latar belakang pendidikan SMA sebesar $58.2 \%$, dan karyawan kontrak dengan masa kerjanya selama 2 tahun dengan persentase sebesar 49.5\%. Pendapatan sebesar Rp 2500 000-Rp 3500000 dengan persentase $66 \%$, dan sebanyak $62.6 \%$ karyawan memiliki tanggungan $1-2$ orang.

\section{III.4. Persepsi Karyawan Kontrak PT ULBC terhadap Kompensasi Finansial Langsung}

Persepsi karyawan kontrak PT ULBC terhadap kompensasi finansial langsung, terdiri dari pembayaran pokok, pembayaran prestasi, pembayaran insentif dan pembayaran tertangguh. Persepesi karyawan kontrak terhadap kompensasi finansial langsung dapat dilihat pada Tabel 5.

1. Pembayaran Pokok

Perusahaan memberikan pembayaran pokok kepada karyawan dalam bentuk gaji dan upah. Berdasarkan persepsi karyawan terhadap pembayaran pokok menjelaskan bahwa sebesar $74.7 \%$ karyawan setuju bahwa perusahaan memberikan gaji sesuai dengan standar umum yang berlaku, yaitu sesuai dengan Upah Minimum Provinsi (UMP). PT ULBC memberikan gaji kepada karyawan sesuai dengan UMP yang diatur 
dalam peraturan perundang-undangan, yaitu dalam peraturan menteri tenaga kerja No.05/Men/1989 tanggal 28 Mei 1989 tentang upah minimum. Pengupahan yang berlaku didasarkan atas jabatan dan fungsi karyawan dalam perusahaan sesuai dengan asas adil dan layak. Upah minimun yang diberikan kepada karyawan tidak kurang dari ketentuan upah minimum yang ditentukan oleh pemerintah DKI Jakarta melalui Peraturan Gubernur Provinsi Daerah Khusus Ibukota Jakarta No. 189 Tahun 2012 tentang Upah Minimum Provinsi Tahun 2013, yaitu sebesar Rp 2200 000. Sebesar 65.9\% karyawan setuju bahwa perusahaan mempertimbangkan kenaikan upah setahun sekali berdasarkan inflasi. Kenaikan upah dipertimbangkan setahun sekali dengan memperhatikan akan faktor inflasi, prestasi, dan kondite kerja masing-masing karyawan. Besarnya kenaikan juga didasarkan kepada kemampuan keadaan perusahaan. Kenaikan upah sebelum masa peninjauan tahunan dapat juga diberikan kepada karyawan yang menunjukkan prestasi kerja luar biasa menurut penilaian perusahaan. Kenaikan upah tersebut diatas, baik tahunan ataupun peninjauan/prestasi kerja luar biasa, berdasarkan upah terakhir yang diterima.

Tabel 5. Persepsi karyawan kontrak terhadap kompensasi financial langsung

\begin{tabular}{|c|c|c|c|}
\hline No. & Pernyataan & $\begin{array}{l}\text { Mayoritas } \\
\text { Jawaban }\end{array}$ & $\begin{array}{l}\text { Persentase } \\
\text { (\%) }\end{array}$ \\
\hline \multicolumn{4}{|c|}{ Pembayaran Pokok } \\
\hline 1. & $\begin{array}{l}\text { Perusahaan memberikan gaji sesuai dengan standar umum yang } \\
\text { berlaku (UMR) }\end{array}$ & Setuju & 74.7 \\
\hline 2. & Gaji yang diberikan perusahaan dapat memenuhi kebutuhan & Setuju & 57.1 \\
\hline 3. & $\begin{array}{l}\text { Pengupahan didasarkan atas jabatan dan fungsi karyawan dalam } \\
\text { perusahaan }\end{array}$ & Setuju & 54.9 \\
\hline 4. & $\begin{array}{l}\text { Perusahaan mempertimbangkan kenaikan upah setahun sekali } \\
\text { berdasarkan inflasi }\end{array}$ & Setuju & 65.9 \\
\hline \multicolumn{4}{|c|}{ Pembayaran Prestasi } \\
\hline 1. & $\begin{array}{l}\text { Perusahaan memberikan bonus yang sama besar setiap tahun } \\
\text { kepada seluruh karyawan }\end{array}$ & Tidak Setuju & 34.1 \\
\hline 2. & Bonus yang diberikan perusahaan sebesar satu bulan gaji & Setuju & 57.1 \\
\hline 3. & Pemberian bonus dilakukan pada akhir tahun pembukuan & Setuju & 70.3 \\
\hline \multicolumn{4}{|c|}{ Pembayaran Insentif } \\
\hline 1. & Perusahaan memberikan premi kehadiran setiap bulan & Setuju & 45.1 \\
\hline 2. & $\begin{array}{l}\text { Perusahaan memberikan premi kehadiran tambahan } \\
\text { apabila tidak ada absen dalam sebulan }\end{array}$ & $\begin{array}{l}\text { Cukup } \\
\text { Setuju }\end{array}$ & 44.0 \\
\hline 3. & Perusahaan memberikan upah transportasi & Setuju & 72.5 \\
\hline 4. & Perusahaan memberikan upah lembur sesuai standar yang berlaku & Setuju & 60.4 \\
\hline \multicolumn{4}{|c|}{ Pembayaran Tertangguh } \\
\hline 1. & $\begin{array}{l}\text { Karyawan mendapat Tunjangan Hari Raya (THR) yang besarnya } \\
\text { disesuaikan dengan masa kerja }\end{array}$ & $\begin{array}{l}\text { Cukup } \\
\text { Setuju }\end{array}$ & 50.5 \\
\hline 2. & $\begin{array}{l}\text { Pembayaran Tunjangan Hari Raya (THR) akan diberikan selambat- } \\
\text { lambatnya } 2 \text { minggu sebelum Hari Raya Idul Fitri }\end{array}$ & Setuju & 61.5 \\
\hline 3. & Karyawan mendapatkan Tunjangan Hari Tua (THT) & Tidak Setuju & 83.5 \\
\hline
\end{tabular}

\section{Pembayaran Prestasi}

Pembayaran prestasi yang diberikan oleh perusahaan bertujuan untuk menghargai hasil kerja karyawan atas kinerjanya. Berdasarkan persepsi karyawan terhadap pembayaran prestasi, $34.1 \%$ karyawan tidak setuju bahwa perusahaan 
memberikan bonus yang sama besar setiap tahun kepada seluruh karyawan. Pertimbangan perusahaan dalam memberikan bonus tahunan kepada karyawan berdasarkan prestasi perusahaan berbentuk keuntungan perusahaan selama tahun tersebut. Bonus tahunan tersebut akan diberikan kepada karyawan karena perusahaan menilai bahwa keuntungan yang dihasilkan oleh perusahaan merupakan hasil dari kerja keras seluruh karyawan. Sebanyak $70.3 \%$ karyawan setuju bahwa pemberian bonus dilakukan pada akhir tahun pembukuan.

\section{Pembayaran Insentif}

Pembayaran insentif merupakan bentuk pembayaran langsung yang dikaitkan dengan kinerja karyawan terhadap peningkatan produktivitas. Berdasarkan persepsi karyawan terhadap pembayaran insentif, 45.1\% karyawan setuju bahwa perusahaan memberikan premi kehadiran setiap hari. Bagi karyawan pabrik yang bekerja pada shift malam akan diberikan premi sebesar Rp 25000 per hari dengan ketentuan bahwa karyawan yang bersangkutan akan kehilangan haknya atas premi tersebut jika datang terlambat, tidak masuk kerja dengan alasan apapun kecuali cuti atau sakit dengan keterangan dokter. Premi kehadiran tidak berlaku pada karyawan kantor. Sebesar 72.5\% karyawan setuju bahwa perusahaan memberikan upah transportasi. Besarnya upah transportasi tersebut akan ditinjau kembali apabila ada perubahan tarif kendaraan umum. Upah transportasi yang diberikan perusahaan kepada setiap karyawan adalah Rp 600000 per bulan. Bagi karyawan yang menggunakan kendaraan dinas, upah transportasi tersebut ditiadakan.

\section{Pembayaran Tertangguh}

Pembayaran tertangguh merupakan kewajiban perusahaan yang akan diberikan kepada karyawannya dikemudian hari. Berdasarkan persepsi karyawan terhadap pembayaran pokok menjelaskan bahwa sebesar 50.5\% karyawan cukup setuju bahwa karyawan mendapat Tunjangan Hari Raya (THR) yang besarnya disesuaikan dengan masa kerja dan diberikan kepada semua karyawan yang pada waktu pembayaran masih bekerja dan mempunyai masa kerja sebagai berikut:
a. Masa kerja sampai dengan 3 bulan
: nihil
b. Masa kerja 3-6 bulan
: $50 \%$ dari satu bulan upah
c. Masa kerja 6-9 bulan
: $75 \%$ dari satu bulan upah
d. Masa kerja diatas 9 bulan
: $100 \%$ dari satu bulan upah

Komponen upah THR adalah gaji pokok ditambah dengan tunjangan-tunjangan tetap. Pembayaran THR akan diberikan selambat-lambatnya 2 minggu sebelum Hari Raya Idul Fitri. Sebanyak 83.5\% karyawan menjawab tidak setuju bahwa karyawan mendapatkan Tunjangan Hari Tua (THT) yang merupakan penghargaan terhadap jasajasa keryawan selama bekerja pada perusahaan yang diperhitungkan sesuai dengan Peraturan Pemerintah. Tunjangan tersebut diberikan hanya kepada karyawan tetap perusahaan yang telah mencapai usia 55 tahun. 
III.5. Persepsi Karyawan Kontrak PT ULBC terhadap Kompensasi Finansial Tidak Langsung

Persepsi karyawan kontrak PT ULBC terhadap kompensasi finansial tidak langsung, terdiri dari proteksi, komisi luar jam kerja dan fasilitas. Persepesi karyawan kontrak terhadap kompensasi finansial tidak langsung dapat dilihat pada Tabel 6 .

Tabel 5. Persepsi karyawan kontrak terhadap kompensasi finansial tidak langsung

\begin{tabular}{|c|c|c|c|}
\hline No. & Pernyataan & $\begin{array}{l}\text { Mayoritas } \\
\text { Jawaban }\end{array}$ & $\begin{array}{l}\text { Persentase } \\
\text { (\%) }\end{array}$ \\
\hline \multicolumn{4}{|c|}{ Proteksi } \\
\hline 1. & Karyawan mendapatkan jaminan asuransi (Jamsostek) & Setuju & 74.7 \\
\hline 2. & $\begin{array}{l}\text { Karyawan diasuransikan terhadap kecelakaan diri di luar } \\
\text { jam kerja }\end{array}$ & Setuju & 64.8 \\
\hline \multicolumn{4}{|c|}{ Komisi Luar jam Kerja } \\
\hline 1. & Perusahaan memberikan izin cuti tahunan kepada karyawan & Setuju & 74.7 \\
\hline 2. & Perusahaan memberikan izin cuti hamil kepada karyawan & Setuju & 72.5 \\
\hline 3. & Perusahaan mengadakan program darmawisata bersama & Setuju & 78.0 \\
\hline \multicolumn{4}{|c|}{ Fasilitas } \\
\hline \multirow[t]{2}{*}{1.} & Perusahaan menyediakan kantin dan makan siang untuk karyawan & Cukup & 44.0 \\
\hline & & Setuju & \\
\hline 2. & Perusahaan menyediakan sarana peribadatan untuk karyawan & Setuju & 64.8 \\
\hline 3. & $\begin{array}{l}\text { Perusahaan menyediakan fasilitas pengobatan yang diberikan oleh } \\
\text { dokter perusahaan dan dokter yang disetujui oleh perusahaan }\end{array}$ & Setuju & 80.2 \\
\hline 4. & Perusahaan menyediakan fasilitas kerja yang baik & Setuju & 82.4 \\
\hline 5. & Perusahaan memberikan seragam pada karyawan & Setuju & 58.2 \\
\hline 6. & $\begin{array}{l}\text { Perusahaan menyediakan alat-alat perlengkapan keselamatan } \\
\text { kerja }\end{array}$ & Setuju & 82.4 \\
\hline
\end{tabular}

\section{Proteksi}

Proteksi merupakan perlindungan yang diberikan perusahaan terkait dengan keamanan serta keselamatan kerja karyawannya. Berdasarkan persepsi karyawan terhadap pembayaran pokok menjelaskan bahwa sebesar $74.7 \%$ karyawan setuju bahwa mereka mendapatkan jaminan asuransi (Jamsostek). Apabila karyawan mendapat mendapat kecelakaan sesuai dengan yang dimaksud dalam Undang-undang Kecelakaan Kerja, maka perusahaan akan memberikan ganti rugi sesuai peraturan dalam Undang-undang No. 3 Tahun 1992 dengan jenis ganti rugi berupa biaya pengangkutan karyawan dari tempat kecelakaan ke rumahnya atau rumah sakit, biaya perawatan dan pengobatan, biaya penguburan, serta tunjangan kecelakaan. Sebanyak 64.8\% karyawan setuju bahwa mereka mendapatkan asuransi terhadap kecelakaan diluar jam kerja. Selain Jamsostek, karyawan diasuransikan terhadap kecelakaan diri diluar jam kerja. PT ULBC bekerja sama dengan PT Chartis Insurance Indonesia menerbitkan polis asuransi pribadi untuk kecelakaan perjalanan bisnis. Asuransi ini, dimaksudkan untuk memberikan pertanggungan bagi karyawan yang mengalami kerugian finansial akibat dari kecelakaan perjalanan untuk bisnis perusahaan.

2. Komisi Luar Jam Kerja

Komisi luar jam kerja yang diberikan di perusahaan yaitu kebijakan pemberian izin cuti dan liburan. Berdasarkan persepsi karyawan terhadap pembayaran pokok menjelaskan bahwa sebanyak $74.7 \%$ karyawan setuju bahwa perusahaan memberikan 
izin cuti tahunan kepada karyawan. Karyawan yang bekerja selama 12 bulan dengan tidak terputus berhak atas cuti tahunan selama 12 hari kerja dengan upah penuh. Penggunaan hak atas cuti tahunan harus diajukan kepada pimpinan perusahaan 1 minggu sebelumnya secara tertulis, terkecuali ada musibah.

Sebanyak 78\% karyawan setuju bahwa perusahaan mengadakan program darmawisata bersama. Setiap tahunnya perusahaan mengadakan 2 kali program darmawisata dengan biaya yang ditanggung oleh perusahaan, yaitu Sharing of Joy dan Family Day.

\section{Fasilitas}

Perusahaan perlu menyediakan dan memperhatikan kondisi fasilitas yang diperlukan oleh karyawan dalam menyelesaikan pekerjaannya. Berdasarkan persepsi karyawan terhadap pembayaran pokok menjelaskan bahwa $80.2 \%$ karyawan setuju perusahaan menyediakan fasilitas pengobatan yang diberikan oleh dokter perusahaan dan dokter yang disetujui oleh perusahaan. Perusahaan menyediakan fasilitas pengobatan berupa apotek dan klinik dengan 3 orang dokter jaga yang bertugas secara bergilir. Dokter perusahaan tersebut harus berjaga di klinik pada jam kerja atau selama ada karyawan yang bekerja. Di luar jam kerja, perusahaan memberikan fasilitas pengobatan untuk memelihara kesehatan para karyawan dan keluarganya di rumah sakit yang ditunjuk oleh perusahaan yaitu Rumah Sakit Mitra Internasional, Rumah Sakit Tugu Ibu, dan Rumah Sakit Harapan Bunda, namun jika dalam keadaan darurat karyawan dapat berobat ke rumah sakit lain.

Sebanyak $82.4 \%$ karyawan setuju bahwa perusahaan menyediakan fasilitas kerja yang baik. Karyawan dapat bekerja secara optimal dengan didukung oleh tersedianya fasilitas kerja yang baik. Peralatan kerja pada pabrik berupa mesin-mesin secara teratur diperiksa oleh karyawan teknisi pabrik untuk memastikan keamanan penggunaan alat tersebut. Sistem penerangan dan ventilasi udara pada perusahaan dalam keadaan baik. Perusahaan sangat mengutamakan kebersihan di lingkungan perusahaan dan dalam menjaga kebersihan perusahaan, perusahaan dibantu oleh cleaning service officer. Sebanyak $82.4 \%$ karyawan setuju bahwa perusahaan menyediakan alat-alat perlengkapan keselamatan kerja. Perusahaan akan menyediakan alat-alat perlengkapan keselamatan kerja sesuai dengan jenis dan fungsi pekerjaan masing-masing. Di kantor alat perlengkapan keselamatan kerja yang disediakan berupa fire sprinkler dan Alat Pemadam Api Ringan (APAR) Yamato, sedangkan di pabrik selain terdapat dua alat tersebut, terdapat juga pintu darurat menuju ruang assembly serta petunjuk peringatan yang dipasang pada seluruh daerah berbahaya. Keamanan individu menjadi hal yang sangat diperhatikan ketika bekerja, karyawan pabrik wajib untuk menggunakan masker, penutup kepala, seragam putih, dan sepatu pabrik anti slip.

\section{III.6. Persepsi Karyawan Kontrak terhadap Kinerja Karyawan Kontrak PT ULBC}

Persepsi karyawan kontrak terhadap kinerja karyawan kontrak PT ULBC, terdiri dari kemampuan teknis, kemampuan konseptual, dan kemampuan hubungan interpersonal. Persepsi karyawan kontrak terhadap kinerja karyawan dapat dilihat pada Tabel 7. 


\section{Kemampuan Teknis}

Kemampuan teknis yaitu kemampuan menggunakan pengetahuan, metode, teknik, dan peralatan yang digunakan untuk melaksanakan tugas serta pengalaman dan pelatihan yang diperolehnya. Perusahaan akan menempatkan karyawan pada bidang pekerjaan yang sesuai dengan latar belakang pendidikan, keterampilan, dan pengalaman yang dimiliki, sehingga karyawan dapat menyelesaikan pekerjaan lebih baik. Sebesar $65.9 \%$ karyawan setuju bahwa mereka memahami cara penyelesaian pekerjaan dengan baik. Karyawan dapat menyelesaikan pekerjaan dengan baik karena mereka telah memiliki kompetensi dalam bidang tersebut. Sebesar 69.2\% karyawan setuju bahwa mereka dapat menggunakan peralatan dengan tepat untuk menyelesaikan pekerjaan. Perusahaan menyediakan peralatan kerja sesuai dengan bidang pekerjaan masing-masing dan karyawan dapat mengoperasikan peralatan kerja tersebut sesuai dengan fungsinya.

Tabel 7. Persepsi karyawan kontrak terhadap kinerja karyawan

\begin{tabular}{|c|c|c|c|}
\hline No. & Pernyataan & $\begin{array}{l}\text { Mayoritas } \\
\text { Jawaban }\end{array}$ & $\begin{array}{c}\text { Persentase } \\
\text { (\%) }\end{array}$ \\
\hline \multicolumn{4}{|c|}{ Kemampuan Teknis } \\
\hline \multirow[t]{2}{*}{1.} & Pendidikan dan keterampilan mendukung pelaksanaan pekerjaan & Cukup & 40.7 \\
\hline & & Setuju & \\
\hline 2. & Memiliki pengalaman yang mendukung pelaksanaan pekerjaan & Setuju & 60.4 \\
\hline 3. & Memahami metode penyelesaian pekerjaan dengan baik & Setuju & 65.9 \\
\hline 4. & $\begin{array}{l}\text { Mampu menggunakan peralatan dengan tepat untuk } \\
\text { menyelesaikan pekerjaan }\end{array}$ & Setuju & 69.2 \\
\hline \multicolumn{4}{|c|}{ Kemampuan Konseptual } \\
\hline 1. & Memahami job description dalam melaksanakan tugas sehari-hari & Setuju & 75.8 \\
\hline 2. & Memahami prosedur dalam melaksanakan tugas sehari-hari & Setuju & 76.9 \\
\hline 3. & Bertanggung jawab terhadap pelaksanaan pekerjaan & Setuju & 78.0 \\
\hline 4. & Teliti terhadap hasil kerja dalam menyelesaikan pekerjaan & Setuju & 75.8 \\
\hline 5. & Tepat waktu dalam menyelesaikan pekerjaan & Setuju & 78.0 \\
\hline 6. & Menyelesaikan semua pekerjaan dengan baik & Setuju & 81.3 \\
\hline \multicolumn{4}{|c|}{ Kemampuan Hubungan Interpersonal } \\
\hline 1. & Melakukan komunikasi yang baik dengan atasan & Setuju & 72.5 \\
\hline 2. & Dapat bekerja sama dengan rekan kerja & Setuju & 75.8 \\
\hline 3. & Melakukan komunikasi yang baik dengan rekan kerja & Setuju & 71.4 \\
\hline 4. & Bersedia membantu orang lain dalam menyelesaikan tugas & Setuju & 75.8 \\
\hline 5. & $\begin{array}{l}\text { Memiliki kemampuan beradaptasi dengan cepat di lingkungan } \\
\text { perusahaan }\end{array}$ & Setuju & 78.0 \\
\hline
\end{tabular}

\section{Kemampuan Konseptual}

Kemampuan konseptual yaitu kemampuan untuk memahami kompleksitas perusahaan dan penyesuaian bidang gerak dari unit masing-masing ke dalam bidang operasional perusahaan secara menyeluruh. Pada intinya individual tersebut memahami tugas, fungsi, serta tanggung jawabnya sebagai seorang karyawan. Sebanyak $81.3 \%$ karyawan setuju bahwa mereka dapat meyelesaikan semua tugas dengan baik. Karyawan dapat menyelesaikan pekerjaan sesuai dengan job description masing-masing. Dalam kesehariannya, karyawan harus memahami prosedur dalam melaksanakan pekerjaan, bertangggung jawab terhadap pelaksanaan pekerjaan, teliti terhadap hasil kerja, serta tepat waktu dalam menyelesaikan pekerjaan. Karyawan 
tidak boleh melakukan kecerobohan saat bekerja. Kecerobohan yang terjadi dapat merugikan diri sendiri serta perusahaan. Tugas yang tidak selesai tepat pada waktunya akan mengganggu tugas berikutnya sehingga, ketepatan waktu menjadi hal yang harus diperhatikan dalam menyelesaikan pekerjaan.

\section{Kemampuan Hubungan Interpersonal}

Kemampuan hubungan interpersonal yaitu kemampuan untuk bekerja sama dengan orang lain, memotivasi karyawan, melakukan negosiasi, dan lain-lain. Sebanyak 78\% karyawan setuju bahwa mereka memiliki kemampuan beradaptasi dengan cepat di lingkungan perusahaan, baik dalam melakukan komunikasi dengan atasan, komunikasi yang baik dengan rekan kerja, dan bekerja sama dengan rekan kerja. Hal ini dapat memberikan kemudahan bagi karyawan dalam menjalankan pekerjaannya, mendiskusikan pemasalahan yang dihadapi, serta menciptakan suasana kerja yang nyaman, sehingga karyawan dapat memberikan hasil kerja yang optimal. Sebanyak 75.8\% karyawan setuju bahwa mereka bersedia membantu orang lain dalam menyelesaikan tugas. Hal ini terlihat jelas dalam pelaksanaan pekerjaan di pabrik, yaitu proses produksi, pencampuran, filling dan packing yang dilakukan secara beregu/tim. Tugas yang tidak selesai tepat waktu secara tidak langsung akan mempengaruhi tugas tim lainnya, sehingga dalam satu tim akan saling membantu dalam menyelesaikan tugas tersebut.

\section{III.7. Hubungan Kompensasi Finansial dengan Kinerja Karyawan Kontrak PT ULBC}

Hasil pengolahan data dengan uji korelasi Pearson Product Moment antara kompensasi finansial dengan kinerja karyawansebesar 0.813 menunjukkan bahwa kompensasi memiliki hubungan yang sangat kuat dan positif. Hasil ini sejalan dengan penelitian yang dilakukan oleh Ulfa et al (2013), bahwa terdapat pengaruh antara kompensasi finansial terhadap kinerja karyawan yang sudah terbukti dan hipotesis tersebut terbukti dan dapat diterima, sehingga pelaksanaan dari kompensasi finansial yang diberikan kepada karyawan akan dapat menambah kinerja dari karyawan itu sendiri di dalam penyelesaian pekerjaannya. Semakin baik kompensasi yang diberikan kepada karyawan kontrak maka akan semakin baik kinerja karyawan di perusahaan, sehingga kinerja perusahaan akan semakin baik.

Tingkat signifikansi koefisien yang dihasilkan pada Tabel 8 sebesar 0.000 maka output signifikansi kedua variabel tersebut kurang dari nilai $\alpha$ yaitu 0.05 . Keputusan yang dapat diambil bahwa $\mathrm{H}_{0}$ ditolak artinya ada hubungan antara kompensasi finansial dengan kinerja karyawan kontrak PT ULBC yaitu dengan adanya kompensasi yang baik untuk karyawan kontrak maka akan dapat meningkatkan kinerja karyawan dan meningkat pula kinerja perusahaan. Perusahaan dapat mempertimbangkan kebijakan kompensasi yang berlaku agar tidak menurunkan kinerja karyawan kontrak. Hubungan variabel kompensasi finansial dengan kinerja karyawan dapat dilihat pada Tabel 8. 
Tabel 8. Hubungan variabel kompensasi finansial dengan kinerja karyawan

\begin{tabular}{clcccc}
\hline No. & Kompensasi Finansial & $\begin{array}{c}\text { Nilai } \\
\text { Korelasi }\end{array}$ & $\begin{array}{c}\text { Nilai } \\
\text { Signifikansi }\end{array}$ & $\begin{array}{c}\text { Taraf } \\
\text { Nyata }\end{array}$ & $\begin{array}{c}\text { Hubungan dengan } \\
\text { Kinerja }\end{array}$ \\
\hline 1. & Pembayaran Insentif & 0.616 & 0.000 & 0.05 & Kuat \\
2. & Pembayaran Tertangguh & 0.604 & 0.000 & 0.05 & Kuat \\
3. & Pembayaran Pokok & 0.559 & 0.000 & 0.05 & Kuat \\
4. & Fasilitas & 0.524 & 0.000 & 0.05 & Kuat \\
5. & Komisi Luar Jam Kerja & 0.475 & 0.000 & 0.05 & Cukup Kuat \\
6. & Pembayaran Prestasi & 0.424 & 0.000 & 0.05 & Cukup Kuat \\
7. & Proteksi & 0.302 & 0.004 & 0.05 & Cukup Kuat \\
\hline
\end{tabular}

Nilai korelasi variabel kompensasi finansial pembayaran insentif, pembayaran tertangguh, pembayaran pokok, dan fasilitas memiliki hubungan yang positif dan kuat dengan nilai korelasi berada antara 0.5-0.75 dan nilai signifikansi sebesar 0.000 menunjukkan bahwa terdapat hubungan yang sangat nyata sehingga semakin baik kebijakan perusahaan dalam pembayaran insentif, pembayaran tertangguh, pembayaran pokok, dan fasilitas maka akan semakin baik kinerja karyawan kontrak di perusahaan. Nilai korelasi komisi luar jam kerja, pembayaran prestasi, dan proteksi memiliki hubungan yang positif dan cukup kuat dengan nilai korelasi berada antara 0.25-0.5 dan nilai signifikansi sebesar 0.000 menunjukkan bahwa terdapat hubungan yang sangat nyata sehingga semakin baik kebijakan perusahaan dalam komisi luar jam kerja, pembayaran prestasi, dan proteksi maka akan semakin baik kinerja karyawan kontrak di perusahaan.

\section{III.8. Implikasi Manajerial}

Hasil penelitian menunjukkan bahwa PT ULBC memberikan kompensasi finansial berdasarkan posisi karyawan kontrak di perusahaan, yaitu sesuai dengan jabatan dan fungsi karyawan. Dalam upaya untuk mempertahankan karyawan kontrak yang memiliki kompetensi tinggi serta untuk meningkatkan kinerja karyawan kontrak, maka perusahaan dapat mengubah kebijakan dalam sistem kompensasi yang ada. Pembayaran kompensasi berdasarkan kompetensi dapat menjadi pilihan karena sistem ini dapat meningkatkan motivasi karyawan dalam bekerja, sehingga akan menghasilkan kinerja yang lebih baik. Dalam mengambil kebijakan tersebut, perusahaan perlu membuat perbandingan antara kapabilitas dan pengalaman karyawan kontrak sesuai dengan tuntutan posisi yang didudukinya. Hal ini menyebabkan gaji aktual karyawan kontrak didasarkan pada perbandingan antara kompetensi yang dimiliki individu tersebut terhadap kompetensi ideal untuk posisi yang dijabatnya. Jika karyawan kontrak memiliki tingkat kompetensi yang penuh, maka akan menerima bayaran sesuai reference salary. Sementara jika kompensasinya di bawah tingkat ideal, maka akan menerima bayaran yang lebih rendah dari reference salary. Terdapat pengecualian jika karyawan memiliki kompetensi di atas ideal posisi yang bersangkutan, karyawan tersebut tidak akan memperoleh bayaran ekstra karena kompetensi itu tidak dibutuhkan untuk menjalankan posisinya sekarang. Sebuah peusahaan hanya membayar kompetensi yang dibutuhkan untuk memenuhi tanggung jawab sebuah posisi. 
Hasil penelitian kinerja karyawan kontrak PT ULBC dilihat dari aspek kemampuan teknis, kemampuan konseptual, dan kemampuan hubungan interpersonal menunjukkan bahwa karyawan merasa telah melakukan pekerjaan sesuai dengan aspek tersebut. Untuk meningkatkan kinerja karyawan, perusahaan sebaiknya melakukan melakukan evaluasi pencapaian prestasi kerja karyawan secara berkala, dan memberikan reward kepada karyawan yang memiliki kinerja baik, sehingga dapat memberikan kepuasan kepada karyawan dan dapat meningkatkan kinerja karyawan. Perusahaan selain memberikan pelatihan mengenai safety training, sebaiknya juga memberikan pelatihan intra perusahaan kepada supervisor. Pelatihan tersebut bertujuan untuk melatih individu untuk berani dalam mengambil keputusan.

\section{Kesimpulan}

Berdasarkan hasil analisis penelitian, kesimpulan yang dapat diambil diantaranya sebagai berikut: 1) Pelaksanaan kompensasi finansial pada PT ULBC telah sesuai dengan harapan karyawan kontrak dilihat dari hasil yang diperoleh dari persepsi karyawan kontrak terhadap kompensasi yang menunjukkan bahwa karyawan kontrak memiliki mayoritas jawaban terhadap pernyataan adalah setuju; 2) Kinerja karyawan kontrak pada PT ULBC telah berjalan dengan cukup baik dilihat dari kemampuan teknis, kemampuan konseptual, dan kemampuan hubungan interpersonal; 3) Kompensasi finansial memiliki hubungan yang positif dan kuat dengan kinerja karyawan kontrak PT ULBC.

\section{Daftar Pustaka}

Arep I, Tanjung H. 2003. Manajemen Sumber Daya Manusia. Jakarta (ID): Penerbit Universitas Trisakti.

Fu D. 2012. Study on Innovation in Compensation Management in Modern Enterprise with Incentive Orientation. Di dalam: Kim H, editor. Advances in Technology and Management Proceedings of the 2012 International Conference on Technology and Management [Internet]. [2012, International Convention Center Jeju, JejuIsland, Korea]. Jerman (DE): Springer Berlin Heidelberg. hlm 85-91. Tersedia pada: http:// http://link.springer.com

Lizar A, Sudiro A. 2013. Pengaruh Kompensasi Finansial dan Non Finansial terhadap Kinerja Karyawan pada CV. Virda Elite Collection Malang. Jurnal Ilmiah Mahasiswa FEB. 1(2): 1-21.

Marwansyah. 2010. Manajemen Sumber Daya Manusia. Bandung (ID): Penerbit Alfabeta.

Nasution WA. 2013. Pengaruh Kompensasi Dan Lingkungan Kerja Terhadap Kepuasan Kerja Karyawan Pada PT. Karya Deli Stelindo Medan. Jurnal Manajemen Bisnis STIE IBBI. 20(2): 1-7.

PT Unilever Body Care Indonesia Tbk. 2012. Laporan Tahunan 2012 PT Unilever Body Care Indonesia Tbk. Jakarta (ID): PT Unilever Body Care Indonesia Tbk. 
Rivai V. 2006. Manajemen Sumber Daya Manusia untuk Perusahaan: dari Teori ke Praktik. Jakarta (ID): PT Raja Grafindo Persada.

Ulfa M, Rahardjo K, Ruhana I. 2013. Pengaruh Kompensasi terhadap Motivasi Kerja dan Kinerja Karyawan (Studi pada Karyawan Auto 2000 Malang Sutoyo). Jurnal Administrasi Bisnis. 3(1): 1-16. 